\title{
Monika Cołbecka
}

Uniwersytet Pedagogiczny im. Komisji Edukacji Narodowej w Krakowie, Polska.

Wydział Nauk Humanistycznych

e-mail: monika.colbecka@wp.pl

ORCID ID: 0000-0002-6494-2115

\section{Mateusz Żmudziński}

Archiwum Akt Dawnych Diecezji Toruńskiej, Polska

e-mail: zmudzinski.mateusz@gmail.com

ORCID ID: 0000-0002-8199-5788

\section{otrzeby informacyjne użytkowników archiwów}

\section{kościelnych oraz możliwości ich badania}

\author{
DOI: http://dx.doi.org/10.12775/FT.2019.007
}

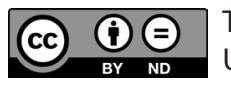

Tekst jest opublikowany na zasadach niewyłącznej licencji Creative Commons Uznanie autorstwa-Bez utworów zależnych 4.0 Międzynarodowe (CC BY-ND 4.0).

Monika Cołbecka jest absolwentką archiwistyki i zarządzania dokumentacją na Wydziale Nauk Historycznych Uniwersytetu Mikołaja Kopernika w Toruniu (dalej: UMK). Od 2019 r. pracuje na stanowisku asystenta w Instytucie Historii i Archiwistyki Uniwersytetu Pedagogicznego im. KEN w Krakowie. Obecnie uczestniczka studiów doktoranckich w zakresie historii na UMK. Realizowany projekt badawczy dotyczy zagadnienia usług informacyjnych świadczonych przez archiwa. Jej zainteresowania badawcze obejmują: teorią archiwalną, informację archiwalną oraz problemy związane z informacyjnym wymiarem archiwistyki.

Dr Mateusz Żmudziński jest absolwentem archiwistyki i zarządzania dokumentacją na Wydziale Nauk Historycznych UMK. Zawodowo związany jest z Archiwum Akt Dawnych Diecezji Toruńskiej (dalej: AADDT), w którym pełni funkcję wicedyrektora. Interesuje się archiwami kościelnymi, zwłaszcza archiwami tzw. świeckiej administracji Kościoła. Do najważniejszych publikacji można zaliczyć Księgi metrykalne w zasobie Archiwum Akt Dawnych Diecezji Toruńskiej. Informator (Toruń 20016) oraz przygotowaną do druku monografię o toruńskim archiwum diecezjalnym. Obecnie jest kierownikiem grantu Naczelnej Dyrekcji Archiwów Państwowych: „Opracowanie, konserwacja i udostępnianie archiwum dokumentowego z Nowego Miasta Lubawskiego przechowywanego w AADDT".

łowa kluczowe: potrzeby informacyjne - badania; użytkownicy archiwów; archiwa kościelne - użytkownicy

\section{$\mathbf{S}$}

treszczenie: Niniejszy tekst poświęcony jest potrzebom użytkowników korzystających z zasobów archiwów kościelnych. Jednak projekt ankiety przygotowany przez autorów wybiega poza ten jeden aspekt badań nad użytkownikami, który wymieniony jest w tytule. Planowane badania mają służyć podniesieniu efektywności informacyjnej danego archiwum, więc po- 
winny dotyczyć potrzeb, ale również zachowań, satysfakcji oraz samych odwiedzających archiwum. Artykuł można podzielić na trzy zasadnicze części. Pierwsza uzasadnia podjęcie tematu badań ukierunkowanych na użytkowników archiwów kościelnych, druga część to przyjrzenie się wybranym badaniom prowadzonym przez biblioteki i archiwa w kraju i za granicą. Ostatnia część to przedstawienie propozycji badania skonstruowanego na podstawie wcześniej wymienionych przykładów.

\section{Wstęp - ważność i aktualność problematyki}

Potrzeby informacyjne użytkowników to problematyka, która w literaturze archiwistycznej przewija się już od kilkunastu, a nawet kilkudziesięciu lat (jeśli weźmiemy pod uwagę teksty, które podejmują tematykę charakterystyki osób odwiedzających archiwa, w których nadmienia się o ich potrzebach) ${ }^{1}$. Dotąd pozostajemy w sferze rozważań teoretycznych. Główny problem, jaki nasuwa się po dokonaniu analizy literatury, to nie sam opis czy próba wyliczenia potrzeb informacyjnych. Podstawowym pytaniem jest to, czy naukowcy i praktycy są w stanie przewidzieć przyszłe potrzeby użytkowników archiwów²?

Podjęta przez nas problematyka jest ważna, potwierdzeniem tej tezy mogą być działania, jakie w ostatnich latach podejmowane są przez władze archiwalne, a są odpowiedzią na światowe tendencje, w których można zauważyć, że towarem najwyższej wartości staje się właśnie informacja. Coraz częściej możemy usłyszeć, że społeczeństwo, w jakim żyjemy, jest „społeczeństwem informacyjnym”. Przeobrażenia społeczne dotykają również archiwów i dlatego też instytucje te nie mogą być na nie obojętne. Naturalny staje się: „powszechny dostęp do Internetu oraz gwałtowny rozwój technologii teleinformatycznych, multiwyszukiwarek, bibliotek cyfrowych, zasobów open access"“. Dla archiwów może to oznaczać przeobrażenia organizacyjne - skierowanie uwagi na użytkownika/klienta archiwum. Tutaj pomocne okaże się czerpanie doświadczeń z dorobku innych nauk informacyjnych, z doświadczeń bibliologów i informatologów.

Coraz więcej działań archiwów kierunkuje się na użytkowników - doskonalenie wykonywanych usług mających na celu zaspokajanie potrzeb informacyjnych użytkowników. Warte odnotowania są prace, które swym działaniem obejmują państwową sieć archiwalną, a także wychodzą poza nią (czego dowodem mogą być właśnie archiwa kościelne). Narodowe Archiwum Cyfrowe (dalej: NAC) jako archiwum centralne koordynuje prace nad elektronicznym systemem informacyj-

\footnotetext{
1 Wymienimy najważniejsze teksty, mogące być uważane w omawianej problematyce za klasyczne: S. Nawrocki, Kształcenie użytkowników informacji w archiwach, Archeion, t. 72: 1981, s. 7-15; S. Nawrocki, Komputer w służbie archiwalnej, Poznań 1985; B. Ryszewski, Problemy i metody badawcze archiwistyki, Toruń 1985; M. Gołembiowski, System informacji archiwalnej, Warszawa-Łódź 1985; M. Gołembiowski, Wprowadzenie do informacji naukowej dla archiwistów, Torun 1991.

2 W. Kwiatkowska, Budowa elektronicznego systemu informacji archiwalnej w Polsce. Stan obecny i perspektywy, Archiwista Polski, 2007, nr 2, s. 83-84; A. Rosa, Użytkownik jako element systemu informacyjnego, [w:] Komputeryzacja i digitalizacja w archiwach, red. R. Leśkiewicz, A. Żeglińska, seria Symposia Archivistica, t. 2, Warszawa 2016, s. 127.

3 Za pierwszą osobę, która użyła tego sformułowania uważa się Tadeo Umesao w roku 1963, za: M. Golka, Czym jest społeczeństwo informacyjne?, Ruch Prawniczy, Ekonomiczny i Socjologiczny, 2005, z. 4, s. 253.

4 E. Czerwińska, A. A. Jańdziak, Potrzeby czytelników wyzwaniem dla bibliotek uczelnianych na przykładzie Biblioteki Głównej Politechniki Opolskiej - 10 lat później, [w:] Unowocześnienie organizacji i metod pracy bibliotek w świetle zmieniających się potrzeb czytelników. Materiały konferencyjne Opole, 16-17 listopada 2011 r., red. W. Matwiejczuk, D. Szczewczyk-Kłos, Opole 2012, s. 81.
} 
no-wyszukiwawczym polskich archiwów. I tak w roku 2007 rozpoczęło pracę nad Zintegrowanym Systemem Informacji Archiwalnej ZoSIA, czyli aplikacją przeznaczoną do opracowania zbiorów archiwalnych na wszystkich poziomach ich hierarchicznej struktury, która już dwa lata później zaczęła być używana przez archiwa państwowe - początkowo w Poznaniu i Lublinie. Obecnie z systemu tego korzysta 116 instytucji, w tym 45 zewnętrznych (we wrześniu 2018 r. ZoSIA została wdrożona m.in. przez Archiwum Akt Dawnych Diecezji Toruńskiej - dalej: AADDT) ${ }^{5}$. Naturalną konsekwencją działań zmierzających do unifikacji opisu archiwalnego w jednej bazie danych było wyjście z informacją o archiwaliach oraz samymi archiwaliami (w postaci skanów) do środowiska internetowego. I tak w roku 2009 w sieci zadebiutował serwis „Szukaj w Archiwach”, który jest ogólnodostępną częścią systemu ZoSIA, dostępnego na stronie internetowej: szukajwarchiwach.pl ${ }^{6}$. Jak informuje NAC na swojej stronie internetowej, instytucja ta prowadzi już badania dotyczące użyteczności tego serwisu?

Zaspokojenie potrzeb użytkowników jako jeden z obecnych priorytetów służb archiwalnych widoczny jest w Strategii Archiwów Państwowych na lata 2010-2020 ogłoszonej przez Naczelnego Dyrektora Archiwów Państwowych. Ze wstępu dowiadujemy się, że działania w niej opisane mają służyć zaspokojeniu potrzeb informacyjnych państwa oraz społeczeństwa oraz zwiększeniu dostępności zasobu archiwalnego on-line ${ }^{8}$. Strategia ta nakłada na archiwa obowiązek zapewnienia powszechnego dostępu do materiałów archiwalnych poprzez zapewnienie każdemu obywatelowi „przyjaznego, ciągłego i bezpiecznego dostępu, w dowolnym miejscu i czasie, do zgromadzonych w archiwach zasobów informacji”.

Powodem podjęcia przez nas tematu potrzeb użytkowników korzystających z zasobów archiwów kościelnych jest wspomniane już wyżej wdrożenie systemu ZoSIA, które będzie służyło do opracowania materiałów archiwalnych w AADDT, którego jeden z autorów niniejszego artykułu jest pracownikiem. Następstwem tych działań w przyszłości będzie udostępnienie informacji o zasobie tego archiwum w Internecie na portalu szukajwarchiwach.pl. Jest to instytucja, która nieustannie przechodzi zmiany, które mają na celu dostosować jego funkcjonowanie do potrzeb użytkowników. Jakie działania do tej pory były podejmowane w archiwum, żeby ułatwić użytkownikowi dotarcie do informacji? Uruchomiono projekt digitalizacji najczęściej udostępnianych archiwaliów, jakimi są księgi metrykalne. Wdrażany jest Zintegrowany System Informacji Archiwalnej, który powinien pozwolić dotrzeć do instytucji szerszemu gronu odbiorców. Oznacza to stopniowe otwarcie na użytkownika, którego potrzeb nie można całkowicie poznać. Jedynym rozwiązaniem jest prowadzenie badań osób odwiedzających archiwum osobiście lub zlecających płatne poszukiwania. Został wydany informator dla użytkowników, który zawiera

\footnotetext{
ZoSIA. Aplikacja dla wszystkich archiwistów [online], [dostęp 2 I 2019]. Dostępny w World Wide Web: https://www. nac.gov.pl/archiwum-cyfrowe/systemy-i-infrastruktura-it/zosia/.

6 Szukajwarchiwach.pl, [online], [dostęp 2 I 2019]. Dostępny w World Wide Web: https://www.nac.gov.pl/archiwumcyfrowe/systemy-i-infrastruktura-it/szukajwarchiwach-pl/

7 Ruszyły badania użyteczności szukajwarchiwach.pl, [w:]Aktualności. NAC [online], [dostęp 3 I 2019]. Dostępny w World Wide Web: https://www.nac.gov.pl/ruszyly-badania-uzytecznosci-szukajwarchiwach-pl/?change_size=f_s1.

8 Strategia Archiwów Państwowych na lata 2010-2020 [online], [dostęp 2 I 2019]. Dostępny w World Wide Web: https://www.archiwa.gov.pl/images/docs/Strategia_archiww_pastwowych_na_lata_2010_2020.pdf.
} 
spis ksiąg metrykalnych z podziałem na parafie, wymienionymi miejscowościami i wsiami wchodzącymi w skład parafii w poszczególnych okresach historycznych, dodatkowo zawierający także zestawienie miejsc przechowywania metrykaliów poza diecezją toruńską9

Wydaje się jednak, że dalsze działania AADDT powinny być prowadzone na podstawie badania potrzeb informacyjnych użytkowników archiwów kościelnych, co spowodowane jest otwarciem się już wkrótce na dużo szersze grono poszukujących informacji o archiwaliach. Będzie to prowadzić do modyfikacji modelu usług, jak również zmiany, a raczej poszerzenia się profilu użytkownika. Krok ten będzie stanowić otwarcie się na użytkownika internetowego, nad którym kontroli archiwista nie ma. Przeprowadzona w momencie wprowadzania nowej aplikacji, służącej utrwalaniu wyników opracowania zasobu w postaci bazy danych, analiza potrzeb dotychczasowych użytkowników „analogowych” pozwoli na przewidzenie tego, czego użytkownik w Internecie może szukać. Jest to najlepszy moment na prowadzenie tego typu badań, pozwoli to na uniknięcie pomyłek, a także zaoszczędzi czas na wprowadzanie ewentualnych modyfikacji opisów w przyszłości.

\section{Definicja użytkownika}

Pojęcie użytkownika archiwum nie wymaga definicji - jest to osoba przychodząca, czy korzystająca z zasobu archiwalnego. Jeśli zajmujemy się potrzebami informacyjnymi, ważne jest określenie ścieżki (ścieżek), jaką użytkownik musi przebyć, żeby uzyskać (lub nie) interesującą go informację - mowa tu o formach udostępniania, a także z jakim przygotowaniem/umiejętnościami użytkownik ten rozpoczyna poszukiwania. Dlatego ważne jest odpowiedzenie na pytanie, kto i w jakim celu przychodzi do archiwum kościelnego, czyli jakie są jego potrzeby informacyjne?

Agnieszka Rosa wyróżniła trzy drogi (modele) udostępniania informacji użytkownikowi (czyli tego, jak informacja do niego dociera) $)^{10}$. Pierwsza z nich - bezpośrednia cechuje się tym, że użytkownik sam poszukuje informacji, opierając się na zbiorze źródeł pochodnych (pomoce ewidencyjno-informacyjne). Rola archiwisty w tym przypadku może ograniczać się jedynie do jego odpowiedzialności jako twórcy tych pomocy archiwalnych - tego, czy użytkownik odnajdzie poszukiwaną przez siebie informację (oczywiście, o ile jest ona w zasobie archiwalnym). Tutaj według autorki efektywność wyszukiwawcza zależy od jakości źródeł pierwotnych i przygotowania użytkownika do prowadzenia poszukiwań. My dodalibyśmy również przygotowanie personelu do prowadzenia szkoleń użytkowników (o ile pomoc taka jest potrzebna i zostanie przez użytkownika zasygnalizowana).

Model drugi - pośredni występuje w przypadku, gdy to archiwista na zlecenie użytkownika prowadzi kwerendę archiwalną. W tym przypadku ważne jest wyartykułowanie swoich potrzeb, a także oczekiwań przez petenta. W tym wypadku efektywność jest oceniana na podstawie relacji użytkownik-archiwista, ponieważ wydaje się zasadne założenie, że archiwista zna zasób oraz potrafi korzystać

\footnotetext{
9 M. Żmudziński, Księgi metrykalne w zasobie Archiwum Akt Dawnych Diecezji Toruńskiej. Informator, Toruń 2016.

10 A. Rosa, op. cit., s. $125-126$.
} 
z systemu źródeł pochodnych. Trzeci model również pośredni, lecz występujący z inicjatywy archiwum, gdzie użytkownik jest biernym, potencjalnym odbiorcą, mogą to być np. wystawy lub lekcje archiwalne. W tym przypadku również ważne jest rozpoznanie potrzeb użytkowników. W ramach badań potrzeb informacyjnych ważne jest zbadanie dwóch pierwszych modeli, ponieważ będą to badania prowadzone z użytkownikami korzystającymi z zasobu - nie potencjalnymi i wyniki mogą służyć do ulepszenia trzeciej ścieżki udostępniania informacji.

Drugim czynnikiem mającym wpływ na zaspokojenie potrzeby, a co za tym idzie osiągnięcie satysfakcji - zadowolenia z pracy archiwum, jest to, z jakim przygotowaniem/umiejętnościami użytkownik rozpoczyna swoje poszukiwania. Według Agnieszki Rosy pod uwagę powinniśmy wziąć tu sześć aspektów ${ }^{11}$ : umiejętność zadania pytania i określenia oczekiwań, co do odpowiedzi; orientację w zasobie i wiedzę historyczno-ustrojową; znajomość struktury zasobu; znajomość metodyki wyszukiwania informacji; umiejętność pracy z archiwaliami; umiejętność poruszania się w pracowni naukowej.

Użytkownikiem archiwum kościelnego jest osoba, która odwiedza archiwum oraz korzysta z archiwaliów w nim zgromadzonych, wytworzonych przez instytucje i organy Kościoła katolickiego. Użytkownikami są osoby, które korzystają z akt do celów prywatnych, naukowych czy urzędowych. Korzystając z doświadczeń pracy w archiwum, można napisać, że są to najczęściej: genealodzy, historycy, studenci i pracownicy naukowi, prawnicy i notariusze prowadzący postępowania spadkowe, czy przedstawiciele mediów. Każdy z użytkowników przychodzi do archiwum z inną potrzebą, która definiuje zakres pracy z konkretnymi materiałami archiwalnymi. Z punktu widzenia archiwisty bardzo istotny jest podział na użytkownika przygotowanego - mającego już doświadczenie w prowadzeniu kwerendy archiwalnej oraz osoby początkujące, które nie miały jeszcze styczności z archiwami, nie znają specyfiki poszukiwań wynikających z ustrojowej struktury zasobu.

W AADDT rozpoczęto zbieranie informacji o potrzebach użytkowników, czy determinantach wizyt realizowanych w pracowni naukowej, wraz z przybyciem pierwszych użytkowników. Wraz z postępującą organizacją pracy archiwum oraz wzrostem liczby użytkowników zmieniał się sposób zbierania informacji o osobach przebywających w pracowni naukowej. Udostępnianie archiwaliów w ciągu pierwszych dwóch lat wiązało się z koniecznością napisania podania. W dokumencie należało podać: imię i nazwisko użytkownika, miejsce zamieszkania, numer i serię dowodu osobistego, numer PESEL, daty poszukiwań w archiwum oraz sygnatury wykorzystywanych jednostek. W 2004 r. wprowadzono pierwszy wzór formularza, który użytkownicy byli zobligowani wypełnić. Zawierał on, oprócz danych wpisywanych uprzednio odręcznie, także cel wizyty, w przypadku studentów - oznaczenie uczelni, tytuł pracy (jeśli była to praca dyplomowa) oraz dane promotora. W 2007 r. kwestionariusz uzupełniono o podanie zespołów, z których użytkownik planuje korzystać. Ostatnia zmiana w blankiecie zaszła w 2015 r., kiedy to dodano miejsce do uzupełnienia informacji o obywatelstwie, podzielono adresy użytkownika na korespondencyjny i zameldowania oraz dodano oświadczenie, że użytkownik

11 Ibidem, s. 128-129. 
wykorzysta dane zgodnie z wypełnionym formularzem, a ewentualnie wydane drukiem prace dostarczy do archiwum ${ }^{12}$.

Ciągłym zmianom podlegały terminy udostępniania archiwaliów, początkowo użytkownicy musieli wcześniej rezerwować termin wizyty. Od dnia 1 września 2004 r. wprowadzono stałe dni i godziny otwarcia. W pierwszych latach funkcjonowania Archiwum udostępniało materiały w poniedziałki i wtorki w godz. 9:00-16:00. Od 2010 r. czas ten wydłużono o piątek w godz. 9:00 do 13:00. Od kwietnia 2017 do grudnia 2018 r. użytkownicy mogli korzystać z akt od poniedziałku do środy w godz. 9:00-16:00. Od grudnia 2018 r. pracownia naukowa jest czynna od poniedziałku do piątku od 9:00 do 16:00, ale użytkownicy muszą się umówić na wizytę z minimum jednodniowym wyprzedzeniem ${ }^{13}$.

Do potrzeb użytkowników względem zgromadzonych archiwaliów zaliczymy przede wszystkim chęć zbudowania lub poszerzenia wiedzy o swoich przodkach. Analizując ankiety użytkowników z lat 2004-2019, widać, że potrzeby prowadzenia badań genealogicznych stanowią zdecydowaną większość powodów, dla których użytkownicy odwiedzają archiwum. Kolejną przyczyną poszukiwań są prowadzone sprawy spadkowe, które zmuszają użytkowników do udokumentowania wszystkich możliwych spadkobierców lub ich braku. Do wizyty w archiwum prowadzą użytkowników również sprawy nadania obywatelstwa Niemiec, dzięki udowodnieniu posiadania niemieckich korzeni. Wiele wizyt w archiwum jest podyktowana ponownym zawieraniem małżeństw. Użytkownicy, dla których akty chrztu wraz z całą księgą znalazły się w archiwum, muszą je odwiedzić, aby otrzymać dokument umożliwiający zawarcie sakramentu małżeństwa. Liczną grupę użytkowników stanowią historycy, pracownicy uniwersyteccy, doktoranci i studenci, którzy wykorzystują archiwalia na potrzeby prowadzonych badań lub realizowanej pracy naukowej. Niewielką grupę klientów archiwum stanowią przedstawiciele mediów, którzy muszą otrzymać zgodę dyrektora archiwum na wykorzystanie źródeł w publikacjach medialnych.

Na przestrzeni ostatnich lat znacząco zmieniły się wymagania użytkowników wobec archiwum. Oczekują oni obecnie szybkiej realizacji złożonych zamówień, często na tzw. „teraz”. Wielokrotnie żalą się na nieczytelne kopie cyfrowe, czy też nieudostępnianie ksiąg będących w konserwacjilub digitalizacji. Coraz częściej użytkownicy przychodzący do instytucji porównują archiwa kościelne z państwowymi, często żądając takich samych zasad udostępniania.

\section{Definicja potrzeby informacyjnej}

Definicji potrzeb informacyjnych użytkowników (głównie bibliotek) w literaturze specjalistycznej - informatologicznej, czy też z pogranicza kognitywistki możemy odnaleźć wiele. Nie jest jednak naszym celem tworzenie nowych lub analizowanie istniejących i próba ich zaimportowania do realiów funkcjonowania archiwum. Skoro jednak podjęta problematyka związana jest z potrzebą informa-

12 Archiwum Akt Dawnych Diecezji Toruńskiej (dalej: AADDT), Akta własne, Ankiety, sygn. AQ 001, AQ 003, AQ 007, AQ 010.

13 AADDT Akta własne, Sprawozdania, Sprawozdanie z działalności Archiwum Akt Dawnych Diecezji Toruńskiej za okres 24 VI 2001 - 31 XII 2003, Sygn. AR 001, k. 6. 
cyjną, zasadne jest przytoczenie chociaż jednej definicji, żeby nasz dalszy wywód miał podstawę teoretyczną. Sabina Cisek wymienia kilka definicji, najogólniejsza z nich mówi, że potrzeba jest „wewnętrznym” stanem mentalnym, stanem umysłu konkretnego, indywidualnego użytkownika, może to być odczuwane poczucie niedoboru, niepokój, uczucie „braku sensu” etc. Badacze dzielą się na dwie grupy: jedni uważają, że potrzeby można poznać w sposób obiektywny, inni uważają, że jest to niemożliwe i dlatego powinno się zaniechać tych badań na rzecz skupienia uwagi na zachowaniach informacyjnych. Kolejne trudności, jakie mogą występować w trakcie projektowania badania i formułowania wniosków, wynikają z cech, jakie potrzebom informacyjnym są przypisywane. A zatem potrzeby są: dynamiczne (mogą zmieniać się w trakcie poszukiwania informacji i jej dalszej analizy); nie zawsze są uświadomione; wpływ na nie ma wiele czynników, także tych „niemerytorycznych”14.

Już z powyższych przesłanek wynika, że zaspokojenie potrzeby informacyjnej użytkownika następuje nie tylko wtedy, kiedy odnajdzie on w zasobie archiwalnym pożądaną informację - nie jest to jedyny czynnik wpływający na ocenę efektywności informacyjnej. Według Joanny Kołakowskiej „Środkiem do zaspokojenia potrzeb użytkowników jest m.in. wysoka jakość proponowanych usług, wprowadzenie marketingu w bibliotekach oraz ocena wyników i działalności, która powinna zależeć od sposobu obsługi klienta, ponieważ satysfakcja użytkownika jest podstawowym wskaźnikiem jakości pracy"15. Cytat odnosi się do bibliotek, jednak równie dobrze słowo to możemy podmienić na „archiwum”, ponieważ oba typy jednostek zajmują się działalnością informacyjną. Jeśli jakość obsługi informacyjnej może mieć wpływ na zaspokojenie potrzeby użytkownika, nasuwa się pytanie, czy istnieje możliwość, że użytkownik odnalazł potrzebną mu informację, jednak wychodzi z archiwum niezadowolony lub też, czy użytkownik może odczuwać zaspokojenie potrzeby informacyjnej, chociaż pożądanej informacji w zasobie archiwum nie odnalazł?

Przykłady badań użytkowników bibliotek i archiwów, które poniżej podamy, pokażą, że nie skupiają się one jedynie na zainteresowaniach badawczych użytkowników. Projektowane badanie użytkowników powinno dać odpowiedź, jakie elementy w analizie użytkowników oraz relacji użytkownik-archiwum stanowią wartość dla efektywności informacyjnej. Wstępne rozeznanie stanowiące podstawę projektowanego badania powinno uwzględniać takie elementy w rozpoznaniu użytkownika, jak: przygotowanie do poszukiwań, przyzwyczajenia i zachowania, wrażliwość, oczekiwania itp.

\section{Przykłady badania potrzeb użytkowników w archiwach, w bibliotekach}

Prowadzone dotąd badania użytkowników instytucji informacyjnych to przede wszystkim badania ankietowe, z różnicami w formie analizy danych oraz

${ }^{14}$ S. Cisek, Użytkownicy informacji [online], [dostęp 5 I 2019]. Dostępny w World Wide Web: http://skryba.inib.uj.ed u.pl/ cisek/BUOS\%20Uzytkownicy\%20informacji\%2012_13/uzytk_info_12_13.pdf.

15 J. Kołakowska, Badanie potrzeb użytkowników biblioteki, Annales Ācadēmiäe Paedagogicae Cracoviensis Studia ad Bibliothecarum Scientiam Pertinentia [online], 2008, vol. 6 [dostęp 5 I 2019]. Dostępny w World Wide Web: https://docplayer.pl/19382065-Badanie-potrzeb-uzytkownikow-biblioteki.html. 
przedstawienia wyników. Podane przez nas poniżej przykłady dotyczą bibliotek, a także doświadczeń z prowadzenia badań w archiwach zagranicznych. Szczególną wartość i podstawę dla skonstruowania kwestionariusza ankiety à propos archiwów kościelnych ma opracowany standardowy, ujednolicony kwestionariusz badań satysfakcji użytkowników bibliotek w Polsce, który stanowił etap prac w ramach realizacji Strategii Stowarzyszenia Bibliotekarzy Polskich na lata 2010-20216. Posiłkujemy się praktyką bibliotekarzy, ponieważ ich doświadczenie w badaniu tej materii jest zdecydowanie większe i bardziej zaawansowane.

Badania, które będziemy omawiać, nie zawsze dotyczą stricte potrzeb użytkowników, ale też służą poznaniu klienta, jego zaangażowaniu, postawie społecznej, a także satysfakcji ze świadczonych przez biblioteki/archiwa usług. Dopiero badając wszystkie te elementy składowe, może wyłonić się pełny obraz potrzeb i oczekiwań użytkowników. Dlatego też pytania, które w ankietach padają, dotyczą takich obszarów, jak: dostosowanie zbiorów do potrzeb użytkowników, systemy informacyjno-wyszukiwawcze, jakość udostępniania, a także stosunek personelu do klientów ${ }^{17}$.

Opisywane w literaturze badania bibliotek dotyczą przede wszystkim jednostek uczelnianych ${ }^{18}$. Ciekawym przykładem badania jest to przeprowadzone blisko dwadzieścia lat temu w latach 1999-2000 przez Zespół II ds. „Badania potrzeb użytkowników bibliotek” w ramach Projektu Tempus JEP 13242-98 pt. „Doskonalenie zarządzania biblioteką jako element zarządzania przez jakość w uczelni wyższej"19, którego analiza danych opierała się na systemie informatycznym. Nie jest to badanie najnowsze, jednak autorzy bardzo skrupulatnie przedstawili jego przebieg - od planowania, poprzez realizację badań, konstrukcję ankiety i analizę danych. Pierwszym etapem było rozpoznanie wstępne poprzez przeprowadzenie sondażu diagnostycznego, w którym zadano respondentom jedno pytanie, tj.: „W jaki sposób twoim zdaniem można poprawić usługi w bibliotece?”. Dzięki temu, zebrano sugestie - opinie użytkowników, które zostały podzielone na cztery kategorie: komputeryzacja biblioteki; zasoby i ich opracowanie; udostępnianie; inne (np. pomoc pracowników w wyszukiwaniu informacji, utworzenie pracowni audio-video). Kolejnym istotnym z punktu projektowanego przez nas badania był etap stworzenia

${ }_{16}$ Badanie satysfakcji użytkowników bibliotek. Standardowy kwestionariusz ankiety [online], [dostęp 5 I 2019]. Dostępny w World Wide Web: http://www.sbp.pl/repository/SBP/strategia/Badanie_satysfakcji_uzytkownikow_bibliotek14_10-1. pdf.

17 B. Kaczor, Jak nas widzą... czyli biblioteka w oczach czytelników: badania ankietowe, Poradnik Bibliotekarza, 1999, nr 3, s. 9.

18 D. Buzdygan, M. Różycka, J. Sobielga, E. Tomczak, Badanie potrzeb użytkowników w bibliotekach akademickich z wykorzystaniem programu LIBRA. Raport z badań, [w:] Międzynarodowa konferencja Zarządzanie przez jakość w bibliotece akademickiej Bydgoszcz-Gniew, 10-13 września2000 r., EBIB Materiały konferencyjne [online], [dostęp 6 I 2019]. Dostępny w World Wide Web: http://eprints.rclis.org/8078/1/badanie_uzytkownikow.pdf; A. Pośnik, K. Umiastowska, Badanie potrzeb użytkowników bibliotek akademickich na przykładzie Biblioteki Szkoły Głównej Handlowej w Warszawie, [w:] Czytelnik czy klient? Ogólnopolska konferencja bibliotekarzy. Biblioteka Główna UMK Toruń 4-6 grudnia 2003 roku, Materiały konferencyjne [online], [dostęp 6 I 2019]. Dostępny w World Wide Web: http://www.ebib.pl/publikacje/matkonf/torun/posnik.php; E, Strzelczyk, Jak nas oceniają użytkownicy? Badanie satysfakcji użytkowników bibliotek systemu biblioteczno-informacyjnego Politechniki Warszawskiej, Przegląd Biblioteczny, 2016, z. 3, s. 407-424; L. Derfert-Wolf, J. Sobielga, E. Strzelczyk, A. Zawałkiewicz, Ogólnopolskie badania satysfakcji użytkowników bibliotek szkół wyższych w 2017 r. - raport [online], [dostęp 6 I 2019]. Dostępny w World Wide Web: https://bu.uwm.edu.pl/sites/default/files/files//dla_nauki/podstawy_prawne_oceny_dorobku/ inne/2018/sprawozdanie_akademickie_2018.pdf.

19 D. Buzdygan, M. Różycka, J. Sobielga, E. Tomczak, op. cit. 
konstrukcji ankiety właściwej. Twórcy, konstruując ją, zwrócili szczególną uwagę na pytania związane z: częstotliwością korzystania z usług biblioteki; wyznaczeniem usług, które są popularne oraz tym, co należy zmienić - jakie dziedziny działalności biblioteki powinny być rozwijane.

Ankieta została podzielona na trzy części. Pierwsza dotyczyła poznania samych użytkowników, uzyskano informacje dotyczące roku i kierunku studiów, statusu na uczelni, częstotliwości odwiedzin. Część druga stanowiła ocenę poziomu satysfakcji użytkowników z usług. I tak dziewięć wybranych usług bibliotecznych poddano ocenie na pięciostopniowej skali. Twórcy wyróżnili następujące usługi:

- Zbiory biblioteczne spełniają moje oczekiwania.

- Katalog komputerowy jest łatwą formą wyszukiwania.

- Stopień komputeryzacji odpowiada moim potrzebom.

- Jestem zadowolony z usług czytelni.

- Jestem zadowolony z kultury obsługi w bibliotece.

- Jestem zadowolony z oferowanych form szkolenia.

- Usługi w wypożyczalni spełniają moje oczekiwania.

- Jestem zadowolony ze sposobów reklamy zbiorów i usług.

- Informacja o zbiorach w katalogach jest wystarczająca.

Część trzecia była już stworzona na podstawie programu komputerowego LIBRA, za pomocą którego użytkownik oceniał wybrane pary zagadnień, wytypowane podczas sondażu diagnostycznego. W ten sposób można było ustalić skalę ważności potrzeb użytkowników. Jakie to były zagadnienia? Zakup czasopism z dziedziny, którą ankietowany studiuje; zakup większej liczby książek z danej dziedziny; zakup większej liczby egzemplarzy danego tytułu; zwiększenie liczby stanowisk z dostępem do Internetu; większa liczba komputerów dla użytkowników; zakup większej liczby baz danych na CD-ROM 12; wydłużenie czasu pracy agend udostępniania zbiorów; wprowadzenie wypożyczeń nocnych i sobotnio-niedzielnych; czas realizacji zamówień; zwiększenie limitu wypożyczeń; wolny dostęp do półek w czytelniach; skrócenie czasu opracowania nowości; utworzenie pracowni audio-video w bibliotece; większa liczba miejsc w czytelniach; automatyczna prolongata; reklama zbiorów i usług; szkolenia. Tak duża liczba poruszanych tematów pozwoliła na przedstawienie wniosków - konkretnych, szczegółowych propozycji działań biblioteki, które mogłyby usprawnić jej działanie pod kątem zadowolenia użytkowników.

Jednym z uwzględnionych celów szczegółowych Strategii Stowarzyszenia Bibliotekarzy Polskich na lata 2010-2021 jest badanie efektywności bibliotek publicznych i pedagogicznych ${ }^{20}$. Stworzony projekt może stanowić dla archiwistów inspirację oraz podstawę stworzenia własnego kwestionariusza ankiety badającej satysfakcję użytkowników. Jak już na wstępie możemy przeczytać, badania takie „mogą się przyczynić do wzrostu zaufania do biblioteki oraz stanowić promocję dla biblioteki w środowisku lokalnym i szerszym.

- Wyniki badania satysfakcji można wykorzystać do analizy strategicznej.

${ }^{20}$ Badanie satysfakcji użytkowników bibliotek... 
- Wyniki badania pozwalają na identyfikację najważniejszych cech oferowanych usług bibliotecznych oraz wskazanie najważniejszych aspektów, na które zwracają uwagę użytkownicy biblioteki.

- Badania mogą pomóc w identyfikacji problemów, kierunków usprawnień i doskonalenia. Wyniki badania mogą się przyczynić do zwiększenia motywacji pracowników biblioteki".

Jednym z głównych celów zespołu przygotowującego projekt było opracowanie standardowego kwestionariusza ankiety badania satysfakcji użytkowników. Autorzy ankiety założyli, że dzięki tym badaniom będzie możliwe ustalenie współczynnika satysfakcji użytkowników (jako kolejnego oceniającego funkcjonalności bibliotek), a ma on się składać z oceny satysfakcji z usług jako całości oraz satysfakcji z każdej usługi wymienionej w ankiecie. W planach jest prowadzenie badania co 3-5 lat, w tym przewidywane są dalsze badania pilotażowe mające na celu poruszanie kolejnych problemów, np. metody doboru próby. Biblioteki chcące uczestniczyć w projekcie będą mogły korzystać $z$ bezpłatnych narzędzi dostępnych na portalu sbp.pl. Jak możemy przeczytać, projekt ma na celu zebranie materiału, który będzie podstawą do opracowania poradnika dla bibliotekarzy prowadzących badania satysfakcji użytkowników bibliotek. Możliwe jest pobranie propozycji kwestionariusza ankiety dla bibliotek: publicznych, pedagogicznych i szkół wyższych.

Badania oparte na wyżej omówionym projekcie są prowadzone, w Internecie możemy odnaleźć raport z ogólnopolskiego badania szkół wyższych przeprowadzonego w roku $2017^{21}$. Zostało ono przeprowadzone $z$ inicjatywy realizatorów projektu „Analiza funkcjonowania bibliotek naukowych” (AFBN), które jest wspierane przez Konferencję Dyrektorów Bibliotek Akademickich Szkół Polskich. Projekt AFBN (Analiza Funkcjonowania Bibliotek Naukowych) w Polsce jest realizowany w ramach inicjatywy Stowarzyszenia Bibliotekarzy Polskich - AFB (Analiza Funkcjonowania Bibliotek). Na stronie internetowej projektu22 możemy przeczytać, że jego nadrzędnym celem jest „wypracowanie standardów dla bibliotek polskich szkół wyższych [...] przez następujące zadania:

- pozyskiwanie danych w celu opracowania wskaźników funkcjonalności,

- opracowywanie metody oceny funkcjonowania bibliotek,

- opracowywanie i publikowanie rocznych raportów,

- prowadzenie badań porównawczych ze wskaźnikami i standardami funkcjonowania bibliotek zagranicznych,

- rekomendowanie wskaźników organizatorom bibliotek, twórcom rankingów oraz innym instytucjom i organizacjom".

Z przeanalizowanej literatury oraz raportów wynika, że bibliotekarze dysponują już zestawem narzędzi i metod pozyskiwania informacji dotyczących satysfakcji oraz potrzeb użytkowników korzystających z różnego typu bibliotek w Polsce. Co ważne, badania takie na skalę ogólnopolską są już prowadzone i koordynowane centralnie.

${ }^{21}$ L. Derfert-Wolf, J. Sobielga, E. Strzelczyk, A. Zawałkiewicz, op. cit.

22 Analiza Funkcjonowania Bibliotek Naukowych raport [online], [dostęp 6 I 2019]. Dostępny w World Wide Web: http://afb.sbp.pl/afbn/o-projekcie,informacje-ogolne. 
Na badania użytkowników związane z korzystaniem z zasobów archiwalnych uwagę zwróciła Agnieszka Długosz-Pysz, która podała przykłady takich działań podejmowanych za granicą. Niestety, w Polsce wciąż brak szeroko zakrojonych badań użytkowników ${ }^{23}$. Autorka wymienia dwa projekty:

- Archives and Records Association National Surveys Group (poprzednio The Public Service Quality Group for Archives and Local Studies) ${ }^{24}$ - jest to organizacja pozarządowa zrzeszająca archiwistów konserwatorów i zarządców dokumentacji na terenie Wielkiej Brytanii i Irlandiii ${ }^{25}$. Organizacja ta przeprowadza badania użytkowników odwiedzających archiwa, projekt ten nosi nazwę The National Survey of Visitors to U.K. Archives oraz użytkowników kontaktujących się z archiwami drogą elektroniczną, czyli Distance Enquiry Services Surveys.

- Archival Metrics - rozwijany w latach 2005-2011, który tworzą naukowcy z trzech uczelni: University of Michigan, University of North Carolina-Chapel Hill i University of Toronto ${ }^{26}$.

The National Survey of Visitors to U.K. Archives jest ankietą, która jest przeprowadzana wśród odwiedzających archiwa brytyjskie co dwa lata. Raport z ostatniego badania z roku 2016²7jest dostępny w sieci i to on zostanie przez nas omówiony ${ }^{28}$. Zgodnie z założeniami twórców pozwala on prześledzić obecne tendencje, a także przynosi materiał porównawczy dla poszczególnych archiwów. W badaniu wzięło udział 114 archiwów, w których łącznie ankietę wypełniło 7814 odwiedzających. Ankieta składała się z pytań pogrupowanych w cztery sekcje dotyczące: powodu wizyty; personelu, świadczonych usług i udogodnień; samej wizyty; wyników poszukiwań oraz informacji o samym użytkowniku. Na początku raportu otrzymujemy krótkie podsumowanie badania - najważniejsze wnioski oraz porównania stanu z okresem z poprzednich prowadzonych badań, w ten sposób otrzymujemy m.in. informacje o: średnim wyniku dotyczącym ogólnej satysfakcji użytkownika z wizyty, satysfakcji z pracy i dostępności personelu, zadowoleniu z jakości zasobów cyfrowych, średnim czasie spędzonym w archiwum, profilu użytkownika.

Sekcja pierwsza dostarcza nam informacji o częstotliwości odwiedzin użytkowników w archiwum, powodów, dla których zdecydowali się na kwerendę oraz tego, jakie poczynili przygotowania przed przyjściem. Wszystkie wyniki zostały przedstawione w formie graficznej wraz z krótkimi komentarzami, w tym z porównaniem z wynikami poprzednich ankiet.

\footnotetext{
${ }_{23}$ W. K. Roman, System informacji archiwalnej wobec współczesnego użytkownika, [w:] Archiwa Polski i Europy. Wspólne dziedzictwo, różne doświadczenia, red. A. Kulecka, Warszawa 2017, s. 230-231.

24 A. Długosz-Pysz, Badania satysfakcji użytkowników archiwów w świetle projektu Archival Metrics, [w:] Diagnostyka w zarządzaniu informacją: perspektywa informatologiczna, red. R. Sapa, Kraków 2017, s. 441.

25 Archives and Records Association. About ARA [online], [dostęp 24 VI 2019]. Dostępny w World Wide Web: https:// www.archives.org.uk/about.html.

${ }^{26}$ A. Długosz-Pysz, op. cit., s. 438

${ }_{27}$ W chwili opublikowania niniejszego tekstu jest już dostępny raport z roku 2018.

28 Survey of Visitors to UK Archives 2016 [online], [dostęp 8 I 2019.]. Dostępny w World Wide Web: http://www.archives. org.uk/images/Public_Services_Quality_Grp/Survey_of_Visitors_to_UK_Archives_-_National_Headline_Report_2016. pdf.
} 
2 (a). Why are you visiting this archive today?

\begin{tabular}{|l|c|c|}
\hline & 2016 & $\mathbf{2 0 1 4}$ \\
\hline Unweighted Count & 7,557 & 6,800 \\
\hline Family history research & $44 \%$ & $49 \%$ \\
\hline Local history research & $30 \%$ & $31 \%$ \\
\hline Academic research & $21 \%$ & $19 \%$ \\
\hline Architectural/building/site research & $11 \%$ & $8 \%$ \\
\hline To gather information for a talk/publication/presentation & $9 \%$ & $9 \%$ \\
\hline To find information relating to my work & $7 \%$ & $8 \%$ \\
\hline To find information for the organisation I volunteer at & $7 \%$ & $6 \%$ \\
\hline Military research & $6 \%$ & $7 \%$ \\
\hline General browsing/familiarising myself with the archive & $5 \%$ & $5 \%$ \\
\hline Accompanying a friend/family member who is undertaking research & $4 \%$ & $4 \%$ \\
\hline Am in the area/here on holiday/have time & $2 \%$ & $3 \%$ \\
\hline Other & $11 \%$ & $10 \%$ \\
\hline
\end{tabular}

The most frequent reason for visiting the archive was to conduct family history research $(44 \%)$, however this has declined since 2014 . Other common reasons were local history research $(30 \%)$ and academic research $(21 \%)$. Some people wrote about the purpose of their visit, with reasons including:

\section{1. Cel kwerendy}

Źródło: Survey of Visitors to UK Archives 2016 [online], [dostęp 8 I 2019]. Dostępny w World Wide Web: http://www.archives.org.uk/images/Public_Services_Quality_Grp/Survey_of_Visitors_to_UK_Archives_-_National_Headline_Report_2016.pdf. 
3. What, if any, of the following did you do to prepare for your visit today?

\begin{tabular}{|l|l|l|}
\hline & $\mathbf{2 0 1 6}$ & $\mathbf{2 0 1 4}$ \\
\hline Unweighted Count & 6,891 & 6,225 \\
\hline Went online to check archive opening times/find directions etc. & $47 \%$ & $44 \%$ \\
\hline Conducted online research & $44 \%$ & $42 \%$ \\
\hline Researched family history resources family tree & $35 \%$ & $38 \%$ \\
\hline Searched archive's online catalogue to find records/reserve documents & $33 \%$ & $30 \%$ \\
\hline Reviewed my research/undertook background reading & $33 \%$ & $34 \%$ \\
\hline Emailed/telephoned archive & $26 \%$ & $27 \%$ \\
\hline Visited library/museum/other organisation & $16 \%$ & $16 \%$ \\
\hline Asked friends/relatives for information & $14 \%$ & $14 \%$ \\
\hline Visited another archive & $14 \%$ & $15 \%$ \\
\hline Other & $12 \%$ & $13 \%$ \\
\hline
\end{tabular}

\begin{abstract}
Nearly half of respondents went online to check archive opening times / find directions before visiting the archive. $44 \%$ of respondents conducted online research before visiting, while a third researched family history resources, searched the archive's online catalogue, and reviewed their research/undertook background reading. A quarter of respondents emailed/telephoned the archive before visiting.
\end{abstract}

II. 2. Podjęte działania, które przygotowywały do wizyty w archiwum

Źródło: Survey of Visitors to UK Archives 2016 [online], [dostęp 8 I 2019]. Dostępny w World Wide Web: http://www.archives.org.uk/images/Public_Services_Quality_Grp/Survey_of_Visitors_to_UK_Archives_-_National_Headline_Report_2016.pdf.

W części pierwszej kolejnej sekcji użytkownicy byli proszeni o ocenę personelu archiwum. Następnie mieli zaopiniować udogodnienia i usługi, wśród których wyszczególniono: recepcję, łatwość znalezienia placówki, fizyczny dostęp do budynku, strefę socjalną (szafki i toaletę), wygląd budynku, godziny otwarcia, sprzęt komputerowy i zasoby online, dostępność miejsc pracowni naukowej, system udostępniania, zamawiania, kopiowanie i fotografowanie dokumentów, jakość pomocy archiwalnych i mikrofilmów oraz na koniec wystawić ogólną ocenę satysfakcji z usług archiwum.

W sekcji związanej z wizytą w archiwum respondenci odpowiadali na trzy pytania dotyczące: środka transportu, jakim dotarli do archiwum, tego, co użytkownicy robią w okolicy archiwum poza prowadzeniem badań, a także ile czasu spędzili podczas bieżącej wizyty. Ciekawe jest pytanie dotyczące wyników poszukiwań, a brzmi następująco: „Jakie korzyści czerpiesz z korzystania z archiwów? Proszę wskazać niezależnie od tego, czy zgadzasz się, czy nie, z następującymi stwierdzeniami”. Ocenie podlegały odpowiedzi: 
- Podobało mi się,

- Poszerzyłem moją wiedzę o obszar zainteresowań,

- Inspiruje mnie to do dowiedzenia się więcej,

- Bardziej rozumiem moją społeczność, jej historię i ludzi,

- Uzyskałem nowe umiejętności lub ulepszyłem dotychczasowe.

W ostatniej sekcji użytkownicy byli proszeni o udzielenie informacji na temat swojego wieku, płci, miejsca zamieszkania, a także przynależności etnicznej oraz stanu zdrowia, na koniec padło pytanie o region i z jakiego typu archiwum korzystali.

Distance Enquiry Services Surveys to drugi projekt Archives and Records Association National Surveys Group realizowany również co dwa lata, naprzemiennie z wyżej opisanym. Ankieta prowadzona jest wśród użytkowników kontaktujących się z archiwami poprzez Internet: e-mail, formularz online. Ostatni raport pochodzi z badania przeprowadzonego w 2017 r. ${ }^{29}$ Wzięło w nim udział 55 archiwów, a na ankietę odpowiedziało 2002 respondentów. Z krótkiego podsumowania umieszczonego na początku dowiadujemy się, że większość ankietowanych pochodziła z Europy, głównym powodem takiego kontaktu z archiwum była dzieląca ich od tej placówki odległość, a celem otrzymanie informacji na temat przodków. Otrzymaliśmy również informacje na temat wieku, płci oraz ogólnej satysfakcji respondentów z usług świadczonych przez archiwa. Pytania w tym przypadku nie zostały podzielone na sekcje, a dotyczyły:

- Jak użytkownik dowiedział się o systemie zapytań korespondencyjnych/ elektronicznych?

- Jaki był główny powód skontaktowania się z archiwum?

- Powodów zastosowania elektronicznych dróg kontaktu;

- Różnych rodzajów usług archiwów, w tym jakości treści, jasności i szybkości reakcji oraz opłaty za usługi, stronę internetową i dostępność informacji dwujęzycznych (w tym przypadku chodziło o język walijski);

- Od jak dawna użytkownik kontaktuje się tą drogą z archiwum?

- Informacji demograficznych, w tym wieku, płci i regionu.

${ }^{29}$ Distance Enquiry Services Survey 2017 [online], [dostęp 8 I 2019 r.]. Dostępny w World Wide Web: http://www. archives.org.uk/images/Public_Services_Quality_Grp/Distance_Enquiry_Services_Survey_2017_-_Headline_Report. pdf. 
What were your main reasons for using email, letter or other electronic method, e.g. via the web, to contact the Record Office rather than making a personal visit?

\begin{tabular}{|l|c|c|c|}
\hline & \multicolumn{3}{|c|}{ Column \% (Count) } \\
\cline { 2 - 4 } & 2017 & 2015 & 2013 \\
\hline Live too far away to visit & $45 \%(904)$ & $47 \%(1,095)$ & $51 \%(1,107)$ \\
\hline See if archive has relevant information & $34 \%(678)$ & $37 \%(860)$ & $37 \%(805)$ \\
\hline $\begin{array}{l}\text { Email / phone / letter / other electronic } \\
\text { method more convenient }\end{array}$ & $30 \%(603)$ & $31 \%(740)$ & $32 \%(695)$ \\
\hline In advance of a personal visit & $19 \%(379)$ & $23 \%(538)$ & $20 \%(428)$ \\
\hline $\begin{array}{l}\text { Used the archives website but needed } \\
\text { further help or advice }\end{array}$ & $17 \%(345)$ & $16 \%(376)$ & $17 \%(378)$ \\
\hline Saved on travel costs & $12 \%(241)$ & $13 \%(317)$ & $15 \%(330)$ \\
\hline Need advice on services available & $11 \%(210)$ & $12 \%(288)$ & $11 \%(249)$ \\
\hline Don't have time to visit & $6 \%(121)$ & $7 \%(159)$ & $7 \%(148)$ \\
\hline Cannot visit during your opening hours & $5 \%(106)$ & $5 \%(115)$ & $5 \%(112)$ \\
\hline Follow-up to personal visit & $5 \%(97)$ & $4 \%(105)$ & $4 \%(97)$ \\
\hline Other & $3 \%(68)$ & $3 \%(76)$ & $3 \%(70)$ \\
\hline Total & $100 \%(1,992)$ & $100 \%(2,352)$ & $100 \%(2,177)$ \\
\hline Base / Survey response rate & $100 \%(2,002)$ & $100 \%(2,357)$ & $98 \%(2,221)$ \\
\hline
\end{tabular}

The main reasons for contacting the record office remotely were similar in 2017 and 2015 to 2013; the participant lived too far away to visit; they were enquiring about whether they could find relevant information; and it was more convenient than a physical visit.

\section{3. Powody kontaktu online}

Źródło: Survey of Visitors to UK Archives 2016 [online], [dostęp 8 I 2019]. Dostępny w World Wide Web: http://www.archives.org.uk/images/Public_Services_Quality_Grp/Survey_of_Visitors_to_UK_Archives_-_National_Headline_Report_2016.pdf.

Ostatni projekt, który zostanie omówiony, nosi nazwę Archival Metrics. Jest on wspólnym dziełem naukowców z trzech amerykańskich uniwersytetów. Bazował on na doświadczeniach Archives and Records Association National Surveys Group. Jak możemy przeczytać na oficjalnej stronie, projekt ten: „ma na celu promowanie kultury oceniania w dziedzinie archiwalnej poprzez tworzenie standardowych narzędzi oceny, które będą oparte na użytkownikach" ${ }^{30}$. Przygotowane przez zespół zestawy narzędzi służące ocenie są gotowymi pakietami, które zawierają sprawdzone, przetestowane kwestionariusze, instrukcje dotyczące administracji i kodowania oraz przykładowe raporty ilustrujące, jak skutecznie przekazywać wyniki badań innym osobom. Wśród wspomnianych narzędzi, które możemy za darmo pobrać, znajdują się m.in.: kwestionariusz ankiet; dokument pomagający w administrowaniu ankiety, dokument służący przygotowaniu danych do analizy; arkusz kalkulacyjny dla danych uzyskanych z formularza badawczego; przykładowy raport badacza.

Skonstruowanie narzędzi służących poznaniu opinii użytkowników o archiwach odbywało się w kilku etapach. Najpierw przeprowadzono badanie personelu archiwów (pytania dotyczyły użytkowników i możliwości uzyskania ich opinii), ze-

${ }_{30}$ Archival Metrics. About [online], [dostęp 8 I 2019 r.]. Dostępny w World Wide Web: https://sites.google.com/a/umich. edu/archival-metrics/. 
brane dane i wyciągnięte wnioski pozwoliły na stworzenie modelu dalszych działań. Ustalono, że podstawą badania są trzy typy interakcji użytkownika: z personelem, $z$ archiwum oraz z zasobem archiwum. I to na tych obszarach powinna być badana satysfakcja użytkownika ${ }^{31}$.

Jakie elementy zawiera sama ankieta? Na wstępie użytkownik może przeczytać, co ma na celu wypełniany przez niego kwestionariusz, czyli lepsze zrozumienie, w jaki sposób użytkownicy korzystają z archiwum, aby można było poprawić oferowane przez dane archiwum usługi. Wiele punktów stanowią pytania otwarte, i tak jest też w przypadku pierwszego, dotyczącego korzystania z archiwum, gdzie użytkownik proszony jest o określenie celu wizyty, a następnie zaznaczenie, co stało się powodem tej wizyty. W formularzu odpowiedzi można zaznaczyć m.in. pisanie pracy, publikacji, dzieje rodzinne, samo poszukiwanie bez wyznaczonego celu.

Sekcja druga odnosi się do personelu archiwum - użytkownik ocenia pracowników pod względem: ich wiedzy, dostępności, efektywności w wyszukiwaniu materiałów archiwalnych, pomocy oraz podejściu do użytkownika. W kolejnym pytaniu otwartym użytkownik może opisać, w jaki sposób i czy w ogóle personel podczas bieżących odwiedzin pomógł mu. Następna sekcja dotyczy niektórych usług i udogodnień. W tym miejscu twórcy umieścili wprowadzenie do zagadnienia, opisali katalog internetowy zasobu archiwalnego ( $w$ tym miejscu każde archiwum może umieścić nazwę bazy, która podlega ocenie w jej strukturze): jako wykaz i/lub przewodnik po zasobie przechowywanym w archiwum czy bibliotece. Tutaj padają pytania o to, czy użytkownik z danego katalogu korzystał w przypadku obecnej kwerendy, jeśli tak proszony był o ocenę treści, którą w niej odnalazł, łatwości korzystania, przejrzystości użytego w nim języka i ogólnej transparentności. Takie same pytania występują w przypadku tradycyjnych pomocy ewidencyjno-informacyjnych.

Użytkownik proszony jest również o ocenę na skali zadowolenia wielu szczegółowych udogodnień występujących w archiwach, np. temperatura, godziny pracy, oświetlenie, poziom hałasu, fizyczny dostęp do budynku, urządzenia do oglądania mikrofilmów i fiszek, dostęp do Internetu, leksykony, usługi kserograficzne.

31 O szczegółach dotyczących tworzenia narzędzi służących badaniu użytkowników można przeczytać, patrz: A. Długosz-Pysz, op. cit., s. 441-445. 
8. Please indicate your level of satisfaction with the following facilities and services.

Rate each on a scale from 1-5 by checking the appropriate box.

\begin{tabular}{|r|r|r|r|r|r|r|}
\hline & \multicolumn{2}{l|}{$\begin{array}{l}\text { Completely } \\
\text { Dissatisfied }\end{array}$} \\
\hline & \multicolumn{1}{|l}{$\begin{array}{r}\text { Completely } \\
\text { Satisfied }\end{array}$} & $\begin{array}{c}\text { No } \\
\text { opinion }\end{array}$ \\
\hline Hours of service & & & & & & \\
\hline Temperature & & & & & & \\
\hline Lighting & & & & & & \\
\hline Study areas & & & & & & \\
\hline Furniture & & & & & & \\
\hline Informational/ navigational signs & & & & & & \\
\hline Physical Access to the building & & & & & & \\
\hline Microfilm and fiche viewing facilities & & & & & & \\
\hline Internet access & & & & & & \\
\hline Reference books & & & & & & \\
\hline Catalogs/ indexes/ findings aids & & & & & & \\
\hline Website & & & & & & \\
\hline Exhibits & & & & & & \\
\hline Photocopying / duplication services & & & & & & \\
\hline
\end{tabular}

\section{4. Ocena udogodnień}

Źródło: Schemat zawarty w pliku ArchivalMetrics_Researcher_Questionnaire_v1.0, który jest dostępny do ściągnięcia dla użytkowników jako zestaw narzędzi do przeprowadzeni ankiety internetowej na stronie: https://sites.google.com/a/umich.edu/archival-metrics/home/the-toolkits/website-access-tools-survey.

W następnym punkcie użytkownik mógł ocenić, na ile udało mu się osiągnąć cel bieżącej wizyty, a jeśli nie mógł opisać, co pomogłoby mu osiągnąć sukces. W sekcji tej użytkownik został poproszony o zaznaczenie wytypowanych przez twórców punktów, które mogą charakteryzować wizytę w archiwum, i były to:

- To był źle wykorzystany czas.

- Osiągnąłem to, co zamierzałem zrobić.

- Dowiedziałem się czegoś nowego o archiwach.

- Dowiedziałem się czegoś nowego na temat materiałów źródłowych na interesujący mnie temat / obszar zainteresowań.

- Dowiedziałem się czegoś nowego o moim temacie / obszarze zainteresowań.

- Moje podejście do tematu / obszaru zainteresowań uległo zmianie.

Kolejne pytania mają na celu określenie profilu respondenta, pytania te dotyczą: częstotliwości i czasu od jakiego ankietowany korzysta z zasobów archiwalnych; szkoleń archiwistycznych, w jakich ewentualnie uczestniczył. Z trzech pytań kończących ankietę możemy dowiedzieć się o wieku, statusie zawodowym, a także ogólnym stopniu satysfakcji z wizyty w archiwum.

Jak pokazują powyższe przykłady, badania użytkowników archiwów za granicą są podejmowane. W artykule zostały podane przykłady działań w krajach angielskojęzycznych, a są to badania mogące być prowadzone na szeroką skalę, a jednak konstrukcja analizowanych ankiet pozwala na badania mniejszej populacji. Analiza wyników tych badań może dotyczyć jednej jednostki, czy też określonego typu archiwów. Wszystkie powyższe kwestionariusze badawcze mają wspólne obszary badawcze, które odnoszą się do: celu podejmowanych badań, relacji z personelem, 
satysfakcji z istniejących systemów wyszukiwawczych i innych udogodnień oferowanych przez archiwa, korzyści płynących z bieżącej wizyty/kontaktu z archiwum. Jeśli za granicą takie badania są prowadzone i są realizowane z powodzeniem, to warto podjąć próbę zaadaptowania takich praktyk do warunków polskich.

\section{Propozycja badania potrzeb użytkowników w archiwach kościelnych}

Jak wynika z powyżej przytoczonych przykładów, strategia archiwów odnosząca się do poznania potrzeb użytkowników opiera się na zbieraniu informacji na podstawie szeroko zakrojonych badań ankietowych odbywających się cyklicznie. Jest to najszybszy sposób dotarcia do jak największej liczby osób, poza tym ten sposób gromadzenia danych nie jest zanadto absorbujący (wywiad wymaga od użytkownika dużo większego zaangażowania umysłowego oraz czasowego). Opierając się na przeanalizowanych ankietach, wytypowaliśmy obszary badawcze - grupy pytań, jakie powinny znaleźć się w naszej propozycji odnoszącej się do użytkownika archiwum kościelnego, nazwaliśmy je modułami. Ankieta przedstawia się następująco:

I. Moduł dotyczący użytkownika:
A. Status użytkownika.
B. Cel wizyty.
C. Jak wygląda przygotowanie się do wizyty.
D. Częstotliwość korzystania.

II. Moduł dotyczący personelu, udogodnień oraz świadczonych usług archiwalnych:
A. Ocena personelu: kompetencje, kultura obsługi, dyspozycyjność.
B. Ocena udogodnień i usług: łatwość znalezienia placówki, fizyczny dostęp do budynku, strefa socjalna (szafki i toaleta), wygląd budynku, godziny otwarcia, sprzęt komputerowy i zasoby online, dostępność miejsc w pracowni naukowej, proces udostępniania, czas zama- wiania, kopiowanie i fotografowanie dokumentów, jakość pomocy archiwalnych i kopii cyfrowych.

III. Moduł dotyczący wizyty (teraźniejszej):
A. Czy łatwo jest dotrzeć do budynku archiwum?
B. Co poza archiwum znajduje się w okolicy?
C. Korzyści wynikające $z$ obecnego wyniku poszukiwań.
D. Całościowa ocena usług bibliotecznych.

Przedstawiony szkic kwestionariusza ankiety zostanie rozbudowany o konkretne pytania, co stanowić ma kolejny etap naszych badań potrzeb użytkowników, który zakończy się pilotażowym badaniem empirycznym, co w konsekwencji ma stanowić podłoże dla skonstruowania badań cyklicznych. 


\section{Zakończenie}

Instytucje funkcjonujące $w$ dobie społeczeństwa informacyjnego powinny traktować dostęp do informacji priorytetowo. Nie można jednak mówić o jej efektywnym udostępnianiu, kiedy nie poznamy wcześniej potrzeb oraz zachowań użytkowników - klientów. Udostępnianie i oferowanie swoich usług (w przypadku archiwów chodzi tu o informacje zawarte w przechowywanych wieczyście materiałach archiwalnych), dla samego tworzenia opcji dostępu nie ma racji bytu. Praca taka, bez ukierunkowania na potrzeby danej grupy odbiorców, może spowodować, że włożony w nią czas, a także poniesione koszty będą nieadekwatne do osiągniętych efektów.

Przedstawiony przez nas dorobek archiwistów i bibliotekarzy pokazuje, że naukowcy oraz praktycy w tych dziedzinach są świadomi konieczności prowadzenia badań - zadawania pytań użytkownikom, co i w jaki sposób chcą uzyskiwać, korzystając z księgozbiorów bibliotecznych czy zasobów archiwalnych na miejscu oraz w Internecie.

\section{Bibliografia}

Analiza Funkcjonowania Bibliotek Naukowych - wskaźniki efektywności i dane statystyczne. b. d. „Analiza Funkcjonowania Bibliotek Naukowych raport”. Dostęp Styczeń 6, 2019. http://afb.sbp.pl/afbn/o-projekcie,informacje-ogolne.

Ankiety. sygn. AQ 001. Akta własne, Archiwum Akt Dawnych Diecezji Toruńskiej, Polska.

Ankiety. sygn. AQ 003. Akta własne, Archiwum Akt Dawnych Diecezji Toruńskiej, Polska.

Ankiety. sygn. AQ 007. Akta własne, Archiwum Akt Dawnych Diecezji Toruńskiej, Polska.

Ankiety. sygn. AQ 010. Akta własne, Archiwum Akt Dawnych Diecezji Toruńskiej, Polska.

Archival Metrics. b. d. "About." Dostęp Styczeń 8, 2019. https://sites.google. com/a/umich.edu/archival-metrics/.

Archives and Records Association. b. d. "About ARA." Dostęp Czerwiec 24, 2019. https://www.archives.org.uk/about.html.

Buzdygan, Dorota, Mirosława Różycka, Jolanta Sobielga, Elżbieta Tomczak. 2000. „Badanie potrzeb użytkowników w bibliotekach akademickich z wykorzystaniem programu LIBRA. Raport z badań." W Międzynarodowa konferencja Zarządzanie przez jakość w bibliotece akademickiej Bydgoszcz-Gniew, 10-13 września 2000 r., EBIB Materiały konferencyjne. Dostęp Styczeń 6, 2019. http://eprints.rclis. org/8078/1/badanie_uzytkownikow.pdf.

Cisek, Sabina. 2012. „Użytkownicy informacji.” Dostęp Styczeń 5, 2019. http://skryba.inib.uj.edu.pl/ cisek/BUOS\%20Uzytkownicy\%20informacji\%2012_13/ uzytk_info_12_13.pdf.

Czerwińska, Elżbieta, Anna Jańdziak. 2012. „Potrzeby czytelników wyzwaniem dla bibliotek uczelnianych na przykładzie Biblioteki Głównej Politechniki Opolskiej - 10 lat później." W: Unowocześnienie organizacji i metod pracy bibliotek 
w świetle zmieniających się potrzeb czytelników. Materiały konferencyjne Opole, 16-17 listopada 2011 r., red. W. Matwiejczuk, D. Szczewczyk-Kłos: 81. Opole: Wydawnictwo Uniwersytetu Opolskiego.

Derfert-Wolf, Lidia, Jolanta Sobielga, Edyta Strzelczyk, Aldona Zawałkiewicz . 2018. „Ogólnopolskie badania satysfakcji użytkowników bibliotek szkół wyższych w 2017 r. - raport." Dostęp Styczeń 6. https://bu.uwm.edu.pl/sites/default/files/ files//dla_nauki/podstawy_prawne_oceny_dorobku/inne/2018/sprawozdanie_akademickie_2018.pdf.

Derfert-Wolf, Lidia. oprac. 2013. „Badanie satysfakcji użytkowników bibliotek. Standardowy kwestionariusz ankiety." Dostęp Styczeń 5, 2019. http://www.sbp.pl/ repository/SBP/strategia/Badanie_satysfakcji_uzytkownikow_bibliotek14_10-1.pdf.

Długosz-Pysz, Agnieszka. 2017. „Badania satysfakcji użytkowników archiwów w świetle projektu Archival Metrics." W Diagnostyka w zarządzaniu informacją: perspektywa informatologiczna, red. R. Sapa, 437-447. Kraków: Biblioteka Jagiellońska.

Golka, Marian. 2005. „Czym jest społeczeństwo informacyjne?”. Ruch, prawniczy, ekonomiczny i socjologiczny 4: 253-265.

Gołembiowski, Maciej. 1991. Wprowadzenie do informacji naukowej dla archiwistów, Toruń: Wydawnictwo Naukowe UMK.

Gołembiowski, Maciej. 1985. System informacji archiwalnej. Warszawa-Łódź: Państwowe Wydawnictwo Naukowe.

Kaczor, Barbara. 1999. „Jak nas widzą... czyli biblioteka w oczach czytelników: badania ankietowe." Poradnik Bibliotekarza 3: 9.

Kołakowska, Joanna. 2008. „Badanie potrzeb użytkowników biblioteki.” Annales Academiae Paedagogicae Cracoviensis Studia ad Bibliothecarum Scientiam Pertinentia [online] 6. Dostęp Styczeń 5, 2019. https://docplayer.pl/19382065-Badanie-potrzeb-uzytkownikow-biblioteki.html.

Kwiatkowska, Wiesława. 2007. „Budowa elektronicznego systemu informacji archiwalnej w Polsce. Stan obecny i perspektywy." Archiwista Polski 2: 83-84.

Naczelny Dyrektor Archiwów Państwowych. 2010. „Strategia Archiwów Państwowych na lata 2010-2020." Dostęp Styczeń 2. https://www.archiwa.gov.pl/ images/docs/Strategia_archiww_pastwowych_na_lata_2010_2020.pdf.

Narodowe Archiwum Cyfrowe. b.d. „Ruszyły badania użyteczności szukajwarchiwach.pl." Aktualności. Dostęp Styczeń 3, 2019. https://www.nac.gov.pl/ ruszyly-badania-uzytecznosci-szukajwarchiwach-pl/?change_size=f_sl.

Narodowe Archiwum Cyfrowe. b.d. „Szukajwarchiwach.pl.” Dostęp Styczeń 2, 2019. https://www.nac.gov.pl/archiwum-cyfrowe/systemy-i-infrastruktura-it/szukajwarchiwach-pl/.

Narodowe Archiwum Cyfrowe. b.d. „ZoSIA. Aplikacja dla wszystkich archiwistów." Dostęp Styczeń 2, 2019.https://www.nac.gov.pl/archiwum-cyfrowe/ systemy-i-infrastruktura-it/zosia/.

Nawrocki, Stanisław. 1981. „Kształcenie użytkowników informacji w archiwach." Archeion 72: 7-15.

Nawrocki, Stanisław. 1985. Komputer w służbie archiwalnej. Poznań: Naczelna Dyrekcja Archiwów Państwowych w Warszawie. 
Pośnik, Anna, Krystyna Umiastowska. 2003. „Badanie potrzeb użytkowników bibliotek akademickich na przykładzie Biblioteki Szkoły Głównej Handlowej w Warszawie." W Czytelnik czy klient? Ogólnopolska konferencja bibliotekarzy. Biblioteka Główna UMK Toruń 4-6 grudnia 2003 roku, Materiały konferencyjne. Dostęp Styczeń 6, 2019. http://www.ebib.pl/publikacje/matkonf/torun/posnik.php.

Roman, Wanda Krystyna. 2017. „System informacji archiwalnej wobec współczesnego użytkownika." WArchiwa Polski i Europy. Wspólne dziedzictwo, różne doświadczenia, red. A. Kulecka, 230-231. Warszawa: Wydawnictwo Uniwersytetu Warszawskiego.

Rosa, Agnieszka. 2016. „Użytkownik jako element systemu informacyjnego.” W Komputeryzacja i digitalizacja w archiwach. Seria Symposia Archivistica, 2, red. R. Leśkiewicz, A. Żeglińska, 127. Warszawa: IPN

Ryszewski, Bohdan. 1985. Problemy i metody badawcze archiwistyki. Toruń: Wydawnictwo UMK.

Sprawozdania, Sprawozdanie z działalności Archiwum Akt Dawnych Diecezji Toruńskiej za okres 24 VI 2001 - 31 XII 2003. Sygn. AR 001. Akta własne, Archiwum Akt Dawnych Diecezji Toruńskiej, Polska.

Strzelczyk, Edyta. 2016. „Jak nas oceniają użytkownicy? Badanie satysfakcji użytkowników bibliotek systemu biblioteczno-informacyjnego Politechniki Warszawskiej." Przegląd Biblioteczny 3: 407-424.

The Chartered Institute of Public Finance and Accountancy. 2017. „Survey of Visitors to UK Archives 2016”. Dostęp Styczeń 8, 2019.http://www.archives.org.uk/ images/Public_Services_Quality_Grp/Survey_of_Visitors_to_UK_Archives_-_National_Headline_Report_2016.pdf.

The Chartered Institute of Public Finance and Accountancy. 2018. "Distance Enquiry Services Survey 2017." Dostęp Styczeń 8. http://www.archives.org.uk/images/Public_Services_Quality_Grp/Distance_Enquiry_Services_Survey_2017_-_Headline_Report.pdf.

Żmudziński, Mateusz. 2016. Księgi metrykalne w zasobie Archiwum Akt Dawnych Diecezji Toruńskiej: informator. Toruń: o-historii.pl.

Przysłany: 25 VI 2019

Zaakceptowany: 7 VIII 2019 


\title{
Monika Cołbecka
}

Pedagogical University of the Commission of National Education (KEN) in

Cracow, Poland. Faculty of Humanities

e-mail: monika.colbecka@wp.pl

ORCID ID: 0000-0002-6494-2115

\section{Mateusz Żmudziński}

Archive of Old Files of the Toruń Diocese, Poland

e-mail: zmudzinski.mateusz@gmail.com

ORCID ID: 0000-0002-8199-5788

Monika Cołbecka is a graduate in Archival Studies and Document Management at the Faculty of Historical Sciences of Nicolaus Copernicus University in Torun (hereinafter: UMK). She has been working as an assistant at the Institute of History and Archival Sciences of the Pedagogical University of the Commission of National Education (KEN) in Cracow since 2019. Currently, she is a participant of doctoral studies in history at Nicolaus Copernicus University. The research project which she carries out concerns the issue of information services provided by archives. Her research interests include: archival theory, archival information and problems related to the informational dimension of archival science.

Mateusz Żmudziński, PhD, is a graduate in Archival Studies and Document Management at the Faculty of Historical Sciences of Nicolaus Copernicus University. Professionally, he is associated with the Archive of Old Files of the Torun Diocese (hereinafter: AOFTD), in which he holds the post of the deputy director. He is interested in church archives, especially the archives of the so-called secular administration of the Church. The most important publications include Record books in the Archives of Old Files of the Torun Diocese. Reference work (Toruń 20016) and a monograph on the diocesan archive of Torun prepared for printing. Currently, he is the head of the grant of the Supreme Directorate of State Archives: Development, maintenance and access to the archive of files from Nowe Miasto Lubawskie stored in AOFTD.

\section{Information needs of users of church archives}

\section{and the possibilities of examining them}

\author{
DOI: http://dx.doi.org/10.12775/FT.2019.007
}

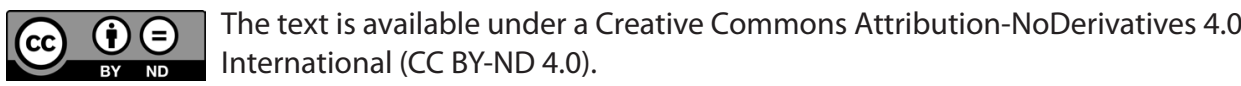

eywords: information needs - research; archive users; church archives - users

ummary: This text addresses the needs of users using the resources of church archives. However, the design of the survey prepared by the authors goes beyond the one aspect of the research on users that is mentioned in the title. The planned research is intended to 
increase the information efficiency of a given archive, so they should concern the needs, the behaviour, the degree of satisfaction and archive visitors themselves. The article can be divided into three main parts. The first justifies taking up the topic of the research aimed at users of church archives, the second part is to look at selected research carried out by libraries and archives at home and abroad. The last part is the presentation of the proposal of the analysis constructed on the basis of the previously mentioned examples. 


\section{Monika Cołbecka}

Pädagogischen Universität in Krakau, Polen. Fakultät der

Geisteswissenschaften

e-mail: monika.colbecka@wp.pl

ORCID ID: 0000-0002-6494-2115

\section{Mateusz Żmudziński}

Archiv der Alten Akten der Thorner Diözese, Polen

e-mail: zmudzinski.mateusz@gmail.com

ORCID ID: 0000-0002-8199-5788

Monika Cołbecka ist Absolventin der Archivkunde und Dokumentationsverwaltung an der Fakultät für Geschichtswissenschaften der Nikolaus-Kopernikus-Universität in Thorn. Seit 2019 arbeitet sie als Dozentin am Institut für Geschichte und Archivkunde der Pädagogischen Universität in Krakau. Derzeit Doktorandin im Bereich Geschichte an der Universität in Thorn. Das von ihr durchgeführte Forschungsprojekt bezieht sich auf die Fragen der Informationsdienste in den Archiven. Ihr Forschungsinteresse umfasst die Archivtheorie und -information sowie die Probleme der Informationsaufgaben der Archivkunde.

Dr. Mateusz Żmudziński ist Absolvent der Archivkunde und Dokumentationsverwaltung an der Fakultät für Geschichtswissenschaften der Nikolaus-Kopernikus-Universität in Thorn, beruflich verbunden mit dem Archiv der Alten Akten der Thorner Diözese, wo er die Funktion des stellvertretenden Direktors erfüllt. Er interessiert sich für Kirchenarchive vor allem im Bereich der weltlichen Kirchenverwaltung. Zu seinen wichtigsten Publikationen rechnet man Księgi metrykalne w zasobie Archiwum Akt Dawnych Diecezji Toruńskiej. Informator (Toruń 2016; Matrikelbücher im Bestand des Archivs der Alten Akten der Thorner Diözese. Ein Führer) sowie eine bereits vorbereitete Monografie über das Thorner Diözesanarchiv. Derzeit Leiter des Projekts der Generaldirektion der Polnischen Staatsarchive: „Bearbeitung, Konservierung und Bereitstellung des Dokumentenarchivs aus Nowe Miasto Lubawskie, aufbewahrt im Archiv der Alten Akten der Thorner Diözese“.

\section{Informationsbedürfnisse der Benutzer von}

\section{Kirchenarchiven sowie die Möglichkeiten}

\section{ihrer Untersuchung}

DOI: http://dx.doi.org/10.12775/FT.2018.007 
tichworte: Informationsbedürfnisse - Untersuchung; Benutzer von Kirchenarchiven; Kirchenarchive - Benutzer

usammenfassung: Dieser Text schildert die Informationsbedürfnisse der Benutzer von Kirchenarchiven, obwohl der Entwurf einer Umfrage, die von den Autoren erarbeitet wurde, nicht nur diese im Titel genannte Forschungsfrage umfasst. Die geplante Untersuchung sollte der Steigerung der Informationseffizienz eines bestimmten Archivs dienen, also die Bedürfnisse, aber auch die Haltung, Satisfaktion und die Benutzer selbst berücksichtigen. Der Beitrag kann in drei Hauptteile gegliedert werden. Der erste von innen begründet die Entscheidung über die Untersuchung der Frage der Benutzer von Kirchenarchiven, der zweite bespricht die Analyse von gewählten Untersuchungen, die in den Bibliotheken und Archiven im In- und Ausland durchgeführt wurden. Der letzte Teil schildert die Forschungsvorschläge, die sich auf die früher erwähnten Beispiele stützen. 